Louisiana State University

LSU Digital Commons

Faculty Publications

Department of Oceanography \& Coastal

Sciences

6-1991

\title{
Tide Gauge Records, Water Level Rise, and Subsidence in the Northern Gulf of Mexico
}

\author{
R. Eugene Turner \\ euturne@Isu.edu
}

Follow this and additional works at: https://digitalcommons.Isu.edu/oceanography_coastal_pubs

\section{Recommended Citation}

Turner, R. (1991). Tide Gauge Records, Water Level Rise, and Subsidence in the Northern Gulf of Mexico. Estuaries, 14 (2), 139-147. Retrieved from https://digitalcommons.Isu.edu/oceanography_coastal_pubs/ 155

This Article is brought to you for free and open access by the Department of Oceanography \& Coastal Sciences at LSU Digital Commons. It has been accepted for inclusion in Faculty Publications by an authorized administrator of LSU Digital Commons. For more information, please contact ir@lsu.edu. 


\title{
Tide Gauge Records, Water Level Rise, and
}

\section{Subsidence in the Northern Gulf of Mexico}

\author{
R. Eugene Turner \\ Department of Marine Sciences and \\ Coastal Ecology Institute \\ Center for Wetland Resources \\ Louisiana State University \\ Baton Rouge, Louisiana 70803
}

\begin{abstract}
Long-term water level changes in the northern Gulf of Mexico were examined using tide gauge records for this century. Strong coherence exists between the annual mean water changes at Galveston, Texas, and (1) the relatively geologically-stable west coast of Florida, (2) global mean sea level, and (3) the subsiding Louisiana coast. Water levels at the Galveston gauge, one of the longest records ( $81 \mathrm{yr}$ ), have risen steadily, but not accelerated over the long-term. The apparent acceleration of water rise in the recent two decades is within the historical pattern, and is probably driven by regional or global, but not local climatic factors. Because eustatic sea level has risen steadily this century, the analysis supports the conclusion that regional geologic subsidence has not varied significantly over the tide gauge record (1909-1988). Variations in the estimates of subsidence in the surface layers are generally consistent with the generally accepted understanding of the geology of deltaic processes on this coast.
\end{abstract}

\section{Introduction}

Tide gauge records from the Gulf of Mexico have been used to estimate eustatic sea level rise (Gornitz et al. 1982), geological subsidence due to compaction and crustal downwarping (Swanson and Thurlow 1973; Penland et al. 1987; Ramsey and Moslow 1987), and the disparity between water level rise and vertical accretion of sediments DeLaune et al. 1978, 1986a, b; Baumann 1980). They are also used to develop management conclusions about increases in sea level rise and geological subsidence, less vertical accretion than relative sea level rise, related secondary interpretations about wetland loss and management (Templet 1987), and estimates of how much oil and gas fluid withdrawal contributes to geologic subsidence (Penland et al. 1987). These latter analyses generally examined tide records of $20 \mathrm{yr}$ or less, thus excluding discussion of longer term variations. An analysis of the available tide gauge records is made to (1) determine sea level rise and settling rates for this century (i.e., geologic subsidence), (2) assess long-term water level variations, and (3) re-evaluate estimates of the balance between eustatic water level changes and sedimentation rates. These analyses were accomplished by establishing coherence between annual water level for records throughout this century, principally at Galveston, Texas, and the many shorter records.

\section{Methods and Materials}

Tide gauge records from $\mathbf{5 5}$ coastal stations ( $\mathrm{Ta}$ ble 1) were analyzed with the assistance of $K$. Ram- sey and S. Penland, Louisiana Geological Survey (LGS), by selecting data sets from two technical reports by the LGS (Penland et al. 1986, 1987) and cross-checking with xerographic copies of the original records supplied by the collecting agency. The two LGS reports include monthly summaries of daily records collected by the U.S. Army Corps of Engineers (COE) and the National Oceanic and Atmospheric Administration (NOAA). Discrepancies between data sets were resolved by examination of the original records in consultation with LGS and updated reports from NOAA supplied as computer data tapes. All staff gauge readings were corrected to adjusted mean sea level, per notations in the original individual gauge records. Several station records contained information to the effect that a nearby water control structure influenced water levels through pumping stations, gates, weirs, or locks; these latter stations were therefore not analyzed further. An estimate of mean global sealevel change is from Barnett (1984). Data from the Galveston Bay, Texas, Pleasure Pier is from Lyles et al. (1988).

Two averages of water levels were used in this analysis. Monthly means are the averages of the reported daily readings for that month. Monthly means were not computed with less than $20 \mathrm{~d}$ data per month. A mean yearly average is the average of the monthly means for that year.

Water level at the Galveston, Texas, Pier 21 station, was analyzed for long-term trends in annual mean water level and for various running averages (10-30 yr) of mean annual water level. Water level 
TABLE 1. Tide gauge record location and record length used for this analysis.

\begin{tabular}{|c|c|c|c|c|c|}
\hline \multirow[b]{2}{*}{$\begin{array}{c}\text { Station } \\
\text { Number }\end{array}$} & \multirow[b]{2}{*}{ Station Name } & \multirow[b]{2}{*}{$\mathrm{R}^{2}$} & \multirow[b]{2}{*}{ Years } & \multicolumn{2}{|c|}{ Comparison to Galveston station } \\
\hline & & & & $\begin{array}{l}\text { Interpreted } \\
\text { Slope \#23 } \\
\text { rise vs others }\end{array}$ & $\begin{array}{l}72 \mathrm{yr} \text { water } \\
\text { rise } \mathrm{cm} \mathrm{yr}\end{array}$ \\
\hline 1 & Calcasicu R. \& Pass near Cameron, LA & 0.78 & 38 & 1.17 & 0.73 \\
\hline 2 & Calcasieu R. \& Pass at Hackberry, LA (Cameron Parish) & 0.76 & 37 & 1.15 & 0.72 \\
\hline 3 & Mermentau R. at Catfish Point Control Structure (S. Auto) & 0.76 & 31 & 1.14 & 0.72 \\
\hline 4 & Schooner Bayou at Control Structure (E. Auto) & 0.75 & 38 & 0.96 & 0.61 \\
\hline 5 & Schooner Bayou at Control Structure (E. Staff) & 0.82 & 37 & 0.96 & 0.60 \\
\hline 6 & Intercoastal Waterway at Vermilion Lock (E. Auto) & 0.78 & 38 & 0.85 & 0.54 \\
\hline 7 & Intercoastal Waterway at Vermilion Lock (E. Staff) & 0.72 & 37 & 0.85 & 0.54 \\
\hline 8 & Intercoastal Waterway at Vermilion Lock (W.) & 0.58 & 38 & - & - \\
\hline 9 & Wax Lake Outlet at Calumet & 0.77 & 38 & 3.37 & 2.12 \\
\hline 10 & Atchafalaya Bay near Eugene Island-COE & 0.71 & 4 & 1.69 & 1.07 \\
\hline 11 & Lower Atchafalaya River at Morgan City, LA & 0.67 & 47 & 2.02 & 1.27 \\
\hline 12 & Bayou Black at Greenwood, LA & 0.84 & 35 & 2.00 & 1.25 \\
\hline 13 & Intercoastal waterway at Houma, LA & 0.51 & 34 & - & - \\
\hline 15 & South Pass Bar Near Port Eads, LA & 0.77 & 32 & 2.04 & 1.28 \\
\hline 16 & Lake Pontchartrain Near South Shore & 0.91 & 31 & 1.22 & 0.77 \\
\hline 17 & Lake Pontchartrain at Little Woods, LA & 0.84 & 45 & 1.42 & 0.89 \\
\hline 18 & Lake Pontchartrain at West End, LA & 0.60 & 47 & 0.68 & 0.43 \\
\hline 19 & Lake Pontchartrain at Frenier & 0.48 & 47 & - & - \\
\hline 20 & Lake Pontchartrain at Mandeville, LA & 0.75 & 49 & 0.70 & 0.44 \\
\hline 21 & Atchafalaya Bay near Eugene Island, LA COF (delta) & 0.85 & 33 & 1.35 & 0.85 \\
\hline 22 & Bayou Rigaud at Grand Isle, LA ( $\# 2$ of 2 ; barrier island) & 0.83 & 28 & 1.07 & 0.67 \\
\hline 23 & Galveston, 'IX & 1.00 & 73 & 1.00 & 0.63 \\
\hline 24 & Port Isabel, TX & 0.84 & 34 & 0.58 & 0.37 \\
\hline 25 & Gulf of Mexico at Biloxi, MS & 0.25 & 27 & - & - \\
\hline 26 & Pensacola, FL & 0.75 & 47 & 0.42 & 0.26 \\
\hline 27 & Cedar Key, FL. & 0.78 & 53 & 0.32 & 0.20 \\
\hline 28 & St. Petersburg, FL & 0.71 & 33 & 0.31 & 0.20 \\
\hline 29 & Key West, FL & 0.76 & 67 & 0.33 & 0.21 \\
\hline 30 & Charenton Drainage Canal near Floodgate & 0.45 & 34 & - & - \\
\hline 34 & Wax Lake vicinity of Belle Isle & 0.72 & 7 & 2.87 & 1.80 \\
\hline 35 & Wax Lake West Drainage area at control structure & 0.31 & 25 & - & - \\
\hline 36 & Intercoastal waterway at Wax Lake W. control structure & 0.84 & 25 & 2.45 & 1.54 \\
\hline 37 & Bayou Teche at $W$. Calumet Floodgate & 0.88 & 29 & 1.44 & 0.91 \\
\hline 38 & Six mile Lake at Verdunville, LA (filled in over last 50 years) & 0.77 & 31 & 4.34 & 2.73 \\
\hline 39 & Round Bayou at Deer Island, LA & 0.07 & 7 & - & - \\
\hline 40 & Lower Atchafalaya River below Sweet Bay Lake (delta) & 0.72 & 24 & 1.91 & 1.20 \\
\hline 41 & Lower Atchafalaya River at Berwick Lock (W.) (delta) & 0.81 & 24 & 1.94 & 1.22 \\
\hline 42 & Bayou Boeuf at B. Boeuf Lock (E.), near Morgan City, LA & 0.79 & 26 & 1.46 & 0.92 \\
\hline 43 & Belle River near Pierre Pass, LA & 0.64 & 23 & 1.60 & 1.00 \\
\hline 44 & Lake Verret, Attakapas Landing, LA & 0.88 & 25 & 2.08 & 1.31 \\
\hline 45 & Bayou Lafourche at Donaldsonville, LA & 0.40 & 20 & - & - \\
\hline 46 & Bayou Boeuf at Amelia, LA & 0.29 & 37 & - & - \\
\hline 47 & Bayou Black at Gibson, LA & 0.78 & 10 & 2.34 & 1.47 \\
\hline 48 & Bayou Lafourche at Thibodaux, LA & 0.01 & 11 & - & - \\
\hline 49 & Bayou Petit Caillou at Cocodrie, LA & 0.78 & 11 & 0.99 & 0.62 \\
\hline 50 & Bayou Lafourche at Valentine, LA & 0.84 & 14 & 1.54 & 0.97 \\
\hline 51 & Bayou Cheureuil near Chegby, LA & 0.71 & 23 & 1.16 & 0.73 \\
\hline 52 & Bayou des Allemands at des Allemands, LA & 0.60 & 30 & 0.84 & 0.53 \\
\hline 53 & Bayou Blue near Catfish Lake, LA & 0.85 & 5 & 0.90 & 0.56 \\
\hline 54 & Bayou Lafourche at Golden Meadow, LA (oilfield/bridge) & 0.86 & 19 & 1.99 & 1.25 \\
\hline 55 & Bayou Lafourche at Leesville, LA & 0.80 & 23 & 0.87 & 0.55 \\
\hline
\end{tabular}

rise at this station began in 1909 , whereas the gauge at Pleasure Pier station began in 1958. A linear regression of annual data from one with the other yielded an $R^{2}$ of 0.81 for the 21 yr recorded in
Lyles et al. (1988). Annual coherence among stations was determined using a simple linear regression analysis of the mean annual water level for one gauge record against the mean annual water 


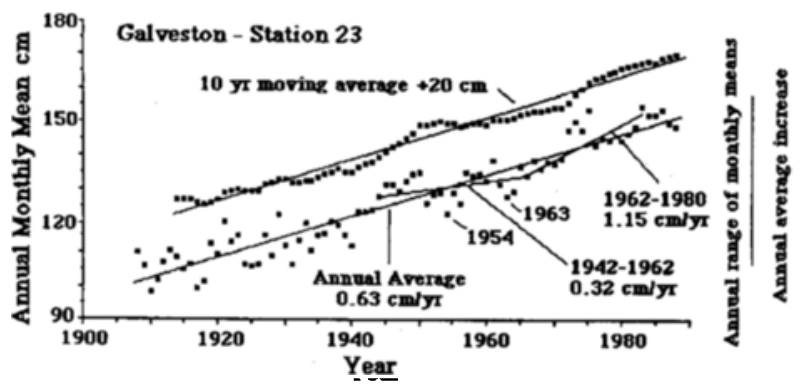

Fig. 1. The annual water level at Galveston, 'Iexas, from 1909 to 1988. 'Two different long-term means are shown together with the linear regression: the annual mean and a 10 yr moving average of the annual mean. Also shown are linear regression relationships between year and mean annual water level for 1942-1962 and for 1962-1982. To the right is the range of water level for the average water level changes over the 81 -yr record and the range of monthly water level for 1950 1979 (see text for details).

level of another gauge. The interpolated 81-yr average water level rise of individual stations in Louisiana was calculated using these correlations in cases where the $R^{2}>0.60$ and years $>10$, by multiplying the slope of the linear regression for the Louisiana gauge by the $81-y \mathrm{r}$ average water level rise at Galveston. A polynomial regression of water level at one station compared to the others was not used because the coefficient of determination, $\mathbf{R}^{2}$, was always higher for the linear regression.

The ages of the Louisiana deltaic subsurface soils are those reported in Frazier (1967) and Penland et al. (1987). Additional recent data are from Smith et al. (1986) for the Atchfalaya delta and Terrebonne Parish wetlands.

\section{Results and Discussion \\ Mean Annual Water Levels}

The Galveston, Texas, Pier 21 tide gauge records were used extensively as a surrogate for investigating long-term water level changes at other stations because of (1) its long record (1908-1988) and (2) the coherence of mean annual water level with those 41 other gauge records. Water levels at Galveston increased $0.63 \pm 0.023(\mu \pm 1 \mathrm{SD}) \mathrm{cm}$ $\mathrm{yr}^{-1}$ for the last $81 \mathrm{yr}$. Ten- and 18-yr running averages of water levels showed relatively constant variation about the mean, a constant increase, but no permanent acceleration over that time period (Fig. 1). Recent average annual water level rise appears to be declining to the long-term rise of this century. These results do not contradict the finding by Penland et al. $(1986,1987,1988)$ that sea level rise in the northern Gulf of Mexico from 1942 to 1962 was well below that from 1962 to 1982 , but puts those changes from one lunar epoch (18.6 yr) to another into an historical perspective. Pen-

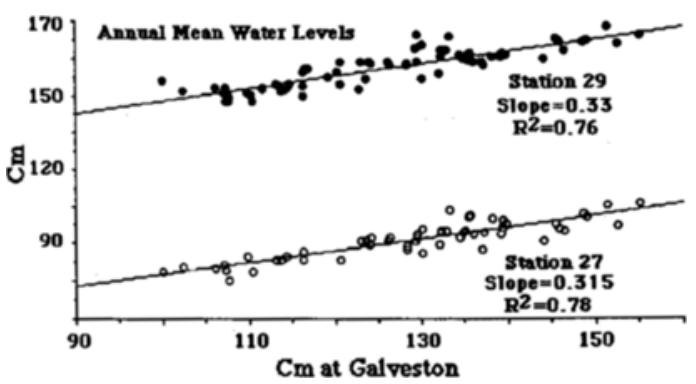

Fig. 2. Mean annual water levels at Galveston compared to Cedar Key, Florida (station 27, 1914-1980) and Key West, Florida (station 29, 1913-1980).

land et al. (1987) indicated that the intervals 1942 1962 and 1962-1982 were periods of increased water level rise, or acceleration, in the northern Gulf of Mexico. This acceleration is observed for the Galveston tide gauge record (from 0.32 to 1.15 $\mathrm{cm} \mathrm{yr}{ }^{-1}$, respectively; Fig. 1). However, from a historical perspective, the acceleration from 1962 to 1982 appears to be short-lived and within the historical variation. This is not to suggest that water level rise at Galveston will not eventually accelerate as a consequence of climatic changes (e.g., in atmospheric carbon dioxide). 'The currently available record at these stations does not conclusively indicate acceleration, but, rather, variation about a long-term mean sea-level rise.

Water levels at the Galveston tide gauge are well correlated with those from (1) the west coast of Florida (Fig. 2), which is considered a relatively geologically stable calcium carbonate platform and therefore subsiding little, if at all, and (2) the global mean sea level $\left(R^{2}=0.90 ; n=70 ;\right.$ Fig. 3$)$. These two unchanging relationships support the hypothesis that mean annual water level rise across the Gulf of Mexico and the world oceans are changing at relatively constant rates and are not accelerating in this century. If geological subsidence at Galveston was accelerating, for example, then the relationships shown in Figs. 2 and 3 would be curvilinear, not linear.

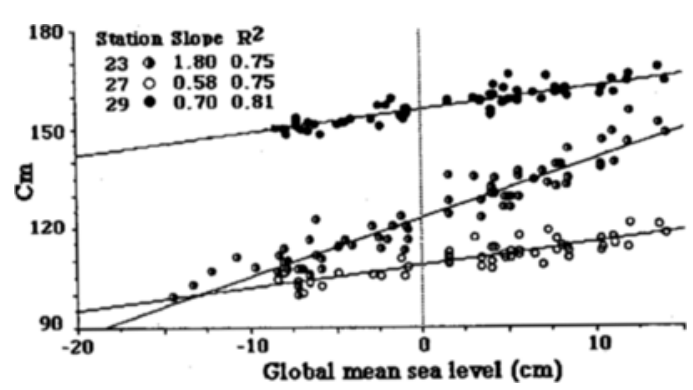

Fig. 3. Mean annual water levels at three stations in the northern Gulf of Mexico compared to the mean global sea level (from Barnett 1984). 

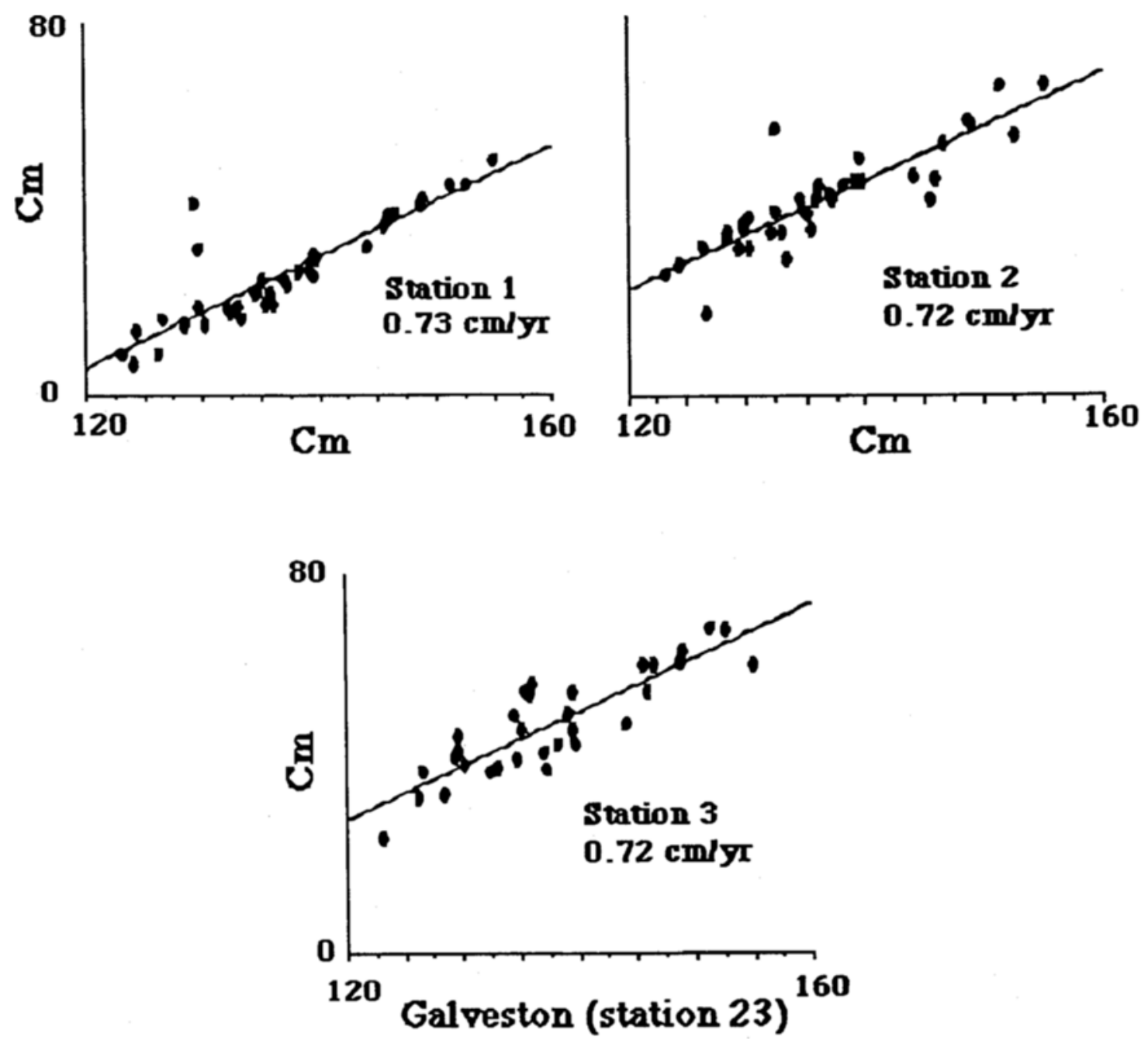

Fig. 4. Annual mean water levels $(\mathrm{cm})$ at Galveston, Texas (station 23) versus annual mean water levels at three stations in southwestern Louisiana, near Cameron. The number in the figure is the estimated long-term water level rise at each station based on this relationship and the long-term record at Galveston.

Annual water levels at Galveston and Louisiana tide gauges are similarly related, although at different ratios than in the two previous examples. Specific examples will be discussed below. For example, the annual water level at the Galveston tide gauge record is well correlated with the shorter term record of annual water levels in southwestern Louisiana (Fig. 4) and Barataria Bay, Louisiana (Fig. 5), located just west of the modern Mississippi River delta. Lack of coherence between the water level at Galveston and Louisiana stations was observed only at stations with short tide gauge records (less than $10 \mathrm{yr}$ ), where pumps or tidal gates were active, at one gas and oil field, or where the newly emerging Atchafalaya River delta is growing near a major river distributary.

The Galveston tide gauge record can therefore be used as a surrogate for relative changes at other gauges where coherence between annual water levels is high $\left(R^{2}>0.60\right)$. Table 1 contains pertinent data on the correlation between annual mean water levels at Galveston and other stations and an estimate of the long-term water level rise based on those correlations. These estimated values range from about 0.2 to $2.7 \mathrm{~cm} \mathrm{yr}^{-1}$ for all stations, and average about $0.90 \mathrm{~cm} \mathrm{yr}^{-1}$ for all Louisiana stations with reliable record quality (i.e., with an $\mathbf{R}^{2}$ $>0.60$ in Table 1). The highest rates of water level rise are where recent sedimentation is the highest (at deltas; $1.37 \mathrm{~cm} \mathrm{yr}^{-1}$; Table 2).

\section{Monthly Variations in Water LeVel.}

Water levels vary daily, seasonally, and over periods longer than lunar cycles (Fig. 1). Water level variation among months is often 10 times higher than variation among years and this can be attrib- 

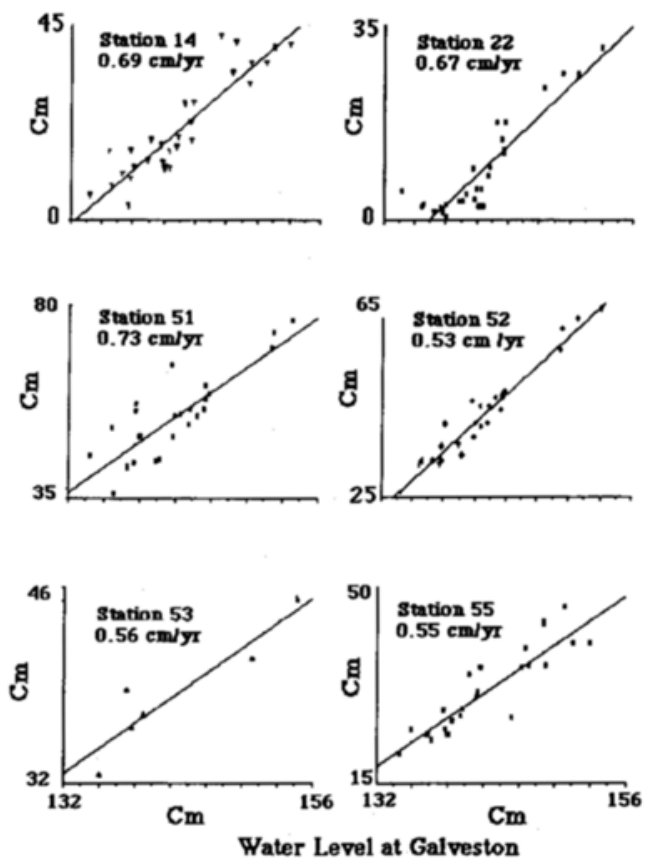

Fig. 5. The relationship between annual mean water level at Galveston, Texas (station 23) and six stations in or near Barataria Bay, Louisiana. The number in the figure is the estimated long-term water level rise at each station based on this relationship and the long-term record at Galveston.

uted to differences in climatic influences (e.g., cold front passages in winter and storm events in summer). It takes little imagination to invoke climatic variability to explain variation among years (e.g., Bradley et al. 1987; Swenson and Turner 1987) because of the observed coincidental variations between wind, water level, temperature, and river discharge over days, months, and years. Knowledge of the sources of within-year variations in sea level is useful to understand these among-year variations, for variations in the former should be related to variations in the latter. The monthly variation in sea levels throughout the Gulf of Mexico (Fig. 6) is low in the winter and high in the late summer. The highest range is exhibited at stations in the central northern Gulf of Mexico. A secondary feature of note is the second minimum occurring in July or August at most stations, but which is weakly developed at the Florida stations. Similar patterns are observed at tide gauge stations in Mexico and Cuba (Marmer 1954; Whitaker 1971).

Most of the monthly variation is due to monthly changes in seawater density (steric effects), probably temperature related, but some related to atmospheric pressure changes related to the passage of winter cold fronts (Whitaker 1971). The secondary minimum might be due to atmospheric changes, tides, or river runoff. Patullo et al. (1955) discounted long-term astronomical tides as a sig-
'IABLE 2. Average water level rises (from Table 1) grouped by geologic setting in Louisiana.

\begin{tabular}{lccr}
\hline \multicolumn{1}{c}{ Geologic Setting } & $\begin{array}{c}\text { Mean } \\
\text { cm yr }\end{array}$ & 1 SE & Number \\
\hline All samples & 0.90 & 0.08 & 42 \\
Passes & 0.72 & 0.005 & 2 \\
Recent deltaic deposits & 1.37 & 0.13 & 9 \\
Bayous and streams & 0.96 & 0.13 & 17 \\
Barrier islands & 0.67 & - & 1 \\
Water control structures & 0.65 & 0.06 & 6 \\
Bridge & 1.25 & - & 1 \\
\hline
\end{tabular}

nificant source of the variation because of their small amplitudes. Local steric effects in shallow water or river runoff might be also another source, but this second trough also appears simultaneously at Casilda, on the south side of Cuba, and at Puerto de Hierro and Cumana, Venezuela, thus implying a regional, not local, phenomenon. Chew (1964) argued that the relaxation of winds in mid-summer was significant enough to produce a large enough variation in onshore transport, and thus contribute to the occurrence of the secondary minimum. Whitaker (1971) observed that seasonal variations in steric effects were sufficient to cause this secondary minimum in the eastern Gulf of Mexico, and disagreed with Chew about the effects of local winds, postulating that this secondary minimum in the western Gulf of Mexico was due to variations in the wind stress in the Caribbean Sea.

The monthly variations in sea level thus appear to be more influenced by steric and atmospheric affects than local runoff or astronomical tides. Variations in these same factors should have a significant effect on annual variations, as well, and may be of different lengths than lunar epochs (18.6 yr).

\section{Long-Term Subsidence Rates}

Water levels may also change because the land sinks from geological (deep) subsidence or from soil oxidation in the shallow surface layers of a marsh (also called subsidence by soil scientists). Recent estimates of global average water level rise are not in complete agreement and range from 0.1 to $0.24 \mathrm{~cm} \mathrm{yr}^{-1}$ (Gornitz and Lebedeff 1987; Peltier and Tushingham 1989). I used Gornitz and Lebedeff's estimate of $0.1 \pm 0.01 \mathrm{~cm} \mathrm{yr}^{-1}$ and subtracted that number from estimates of water level rise obtained from the tide gauge records to estimate subsidence (the combination of geological and soil subsidence). The rise of water level at $42 \mathrm{Lou}-$ isiana tide gauge stations ranges from about 0.2 to $2.7 \mathrm{~cm} \mathrm{yr}^{-1}$ for all stations, and averages about 0.8 $\mathrm{cm} \mathrm{yr} \mathrm{r}^{-1}$ for all stations with reliable record quality (Table 1). The highest rates of water level rise are where recent sedimentation is the highest (at del- 


\section{Monthly A verage Water Levels}
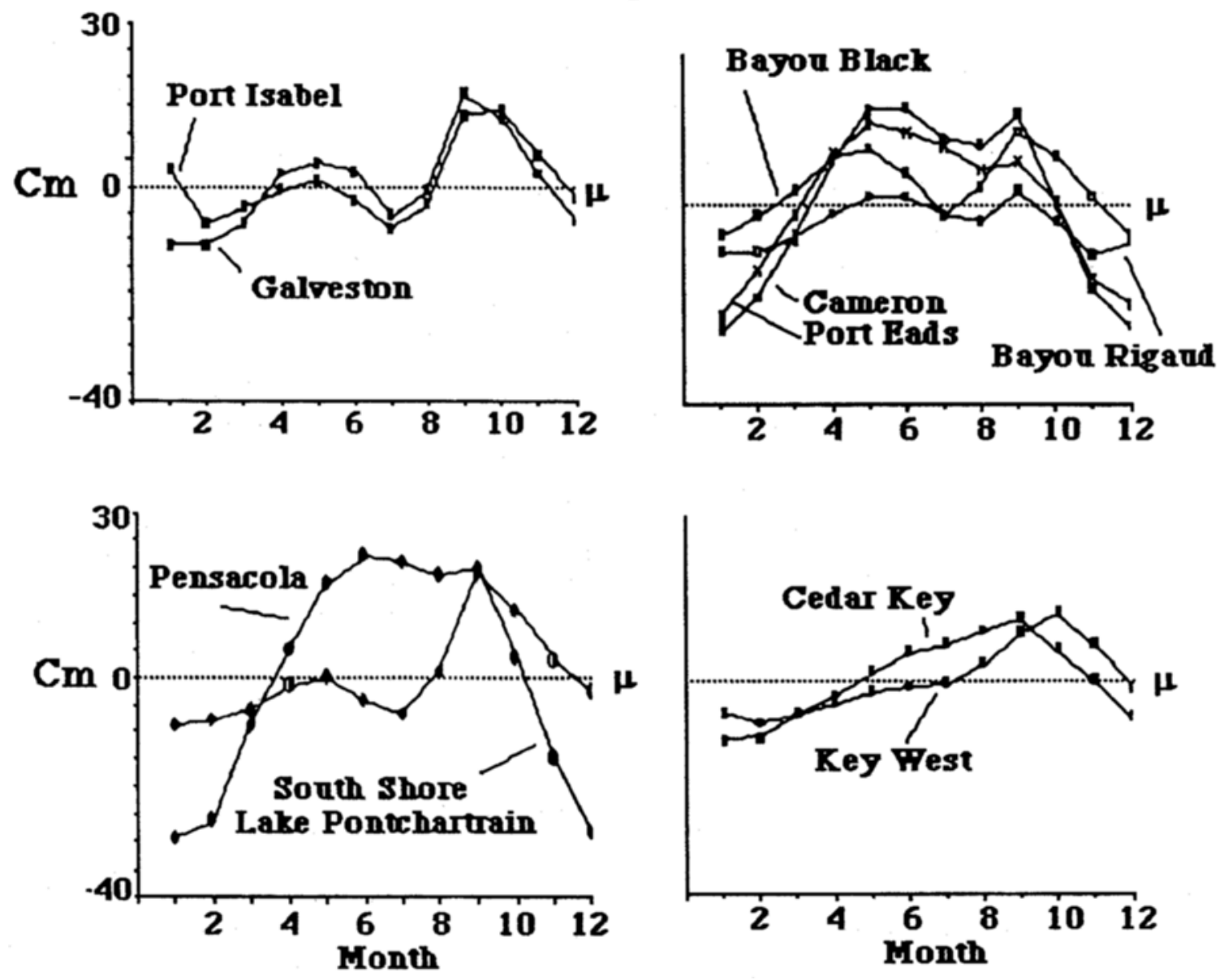

Fig. 6. Monthly average water level from 1950-1979 at 10 tide gauge stations along the Gulf of Mexico coastline.

tas) and where waterway construction and water management is most intense (at locks). The lowest rates tend to be where the depth to the Pleistocene terrace is relatively shallow and where sedimentation is lowest. In effect, relative water level rise recorded on the gauges is lowest where deltaic sediment accumulations are thin and old, and away from barrier islands and man-made water control structures. Crustal downwarping has been continuing over 1,000 s of years, and is assumed constant (Holdahl and Morrison 1974). Thus, changes in the total water level rise due to global sea level ranges from $4 \%$ to $50 \%$ for the locations of the Louisiana tide gauge stations.

Both the rates of global sea level and total relative water level rise in the Gulf of Mexico appear to have been relatively constant this century (Fig. 1; Peltier and Tushingham 1989). Even if a change exists, distinguishing a change this century is not a trivial task given the variability of the station quality, noise : signal ratio, and natural variability (e.g., Barnett 1984). If one assumes that they are constant, then the difference between them, subsidence, is also constant. Also, because of this constancy in the face of fluid withdrawal rates that increased rapidly only in the past few decades, geological subsidence caused by natural factors is much more significant than local changes in subsidence caused by belowground fluid withdrawal. Results from a standard industry model support that conclusion (Suhayda 1987). The exception may be at the Golden Meadow oilfield, where water level rise is about double that at two nearby gauges. However, that station is also located near a state highway; the weight of the bridge may also be dragging down the tide gauge. Another implication is that the recent acceleration of marsh to open water conversions (the past few decades) of $0.8 \%$ annually from 1955 to 1978 (Baumann and Turner 1990) are not the result of recent changes in geological (deep) subsidence; changes in the vertical position of the surface layer, not increases in subsidence in 
the deep layers, are a more likely causal factor driving these recent rises in wetland loss rates.

Subsidence rates in the surface layer are relatively larger than rates in layers beneath. An estimate of subsidence, obtained from carbon isotope dating results, illustrates this point (Fig. 7). The high rate in the first $100 \mathrm{yr}$ is due partially to sediment compaction, soil dewatering, and decomposition. The effects of biological processes probably exceeds geological subsidence only during this first period because the organic content tends to become stable below $2 \mathrm{~m}$ (exclusive of sand layers). The relative water level rise in the later period (after $200 \mathrm{yr}$ ) is around $0.2 \mathrm{~cm} \mathrm{yr}^{-1}$, and is close to the average rise in sea level this century $(0.24 \mathrm{~cm}$ $\mathrm{yr}^{-1}$ for the Florida stations; $0.1 \mathrm{~cm} \mathrm{yr}^{-1}$ globally). Thus, the subsidence rate after $200 \mathrm{yr}$ is relatively very small compared to the first $100 \mathrm{yr}$, or even negligible. Most subsidence takes place in the upper $2 \mathrm{~m}$ of the soil profile because of the shallow depth of the 200-yr horizon.

One must be careful about using tide-gauges to obtain subsidence rates for specific areas for at least four reasons. (1) Total subsidence varies with location. One must not assume that subsidence in the waterway is the same as subsidence in the wetland. (2) Tide gauges were installed to measure water levels, especially to meet the needs of navigation, but not to measure subsidence (Anon 1965). Consequently, their geographic distribution is skewed toward major waterways, they are not distributed amongst inferior marshes, and they are found near the coast and in dredged channels, not in shallow interdistributary bays and marsh ponds. Virtually all of the Terrebonne marshes have no tide gauges, for example. (3) The supports holding the gauge are held in position (at non-standard depths) by both the lateral compression along its entire length, as well as the resistance of the material the supporting post is driven into. Further, the supporting structure may carry additional weight which, in soft sediments, contributes to the downward movement of the tide gauge in the absence of subsidence (e.g., piers, wharfs and bridges). The instruction manual for establishing a tide gauge station specifically suggests, for example, that "A pier maintained for public amusement and recreation often affords an ideal location for a control tide station" (Anon 1965, p. 21). It is not demonstrated to what degree these lateral and terminal pressures contribute to the movement of the gauge on the proximal end. (4) Soil subsidence in the upper $2 \mathrm{~m}$ should not be uniform across broad geographical regions like the Louisiana coast because of large variations in organic content amongst soil types (< $4 \%$ to $43 \%$; Gosselink et al. 1984) and attendant differences in soil respiration rates, flooding re-

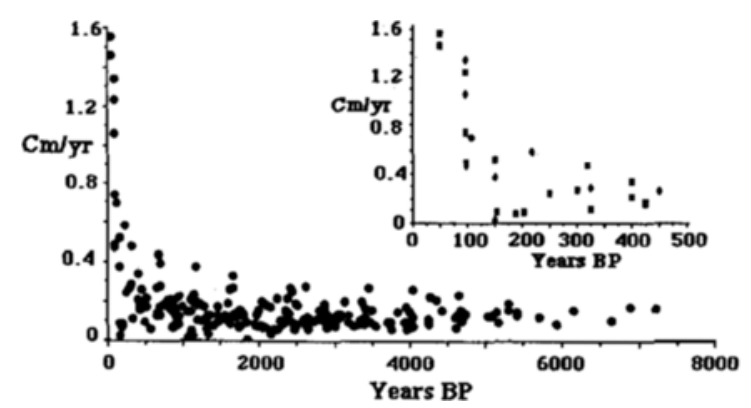

Fig. 7. The burial rates for ${ }^{14} \mathrm{C}$-dated sediments (data are from Frazier 1967 and Penland et al. 1987).

gime, and sediment sources, for example. For these reasons, and others, detailed knowledge of the subsidence rates and influences affecting subsidence rates at many locations at each study site is needed (but not available). Thus, complications, perhaps unavoidable, compromise their use to accurately measure subsidence and caution is therefore recommended.

\section{Sedimentation Deficits}

Negative differences between the vertical accumulation of sediments and water levels have been termed sedimentation deficits (e.g., Baumann et al. 1984). If water level rises faster than the marsh builds vertically, then increased flooding results and plant stress is likely to increase. It is important to choose the correct water level record length to compare to the estimate of vertical growth of the marsh surface, because water level varies over months, years, and decades. The ${ }^{137}$ cesium dating method usually uses the 1963 fallout peak as a marker for the best estimator of vertical accretion. Tide gauge records of water level from 1963 forward are then used to estimate a disparity between annual average water level rise and the measured vertical accretion. This disparity is generally on the order of $10-20 \%$ more water level rise than vertical accretion in the inland marshes from 1963 to the late 1970s (DeLaune et al. 1978, 1983, 1986, 1987; Hatton et al. 1983). As it turns out, the 1963 to 1982 water level change was about $200 \%$ higher than the average for this century (e.g., Fig. 1), because the first few years after 1961 had relatively lower water levels (they declined in 1962 and 1963) and the following years had above-average water level rise. Estimates of water level changes from 1963 to the late 1970 s will therefore be much higher than average, and using that water level record interval in the calculation of vertical accretion disparities may suggest a sedimentation deficit when there is none in the long term (e.g., Table 3). Further, if the marsh vertical accretion is constant this century, then there must have been periods of sed- 
TABLE 3. Estimates of recent sedimentation in back marshes using the ${ }^{137}$ cesium fallout record and from tide gauge records. Levee (also called streamside) marshes are excluded and always have a higher estimated sedimentation rate.

\begin{tabular}{|c|c|c|c|}
\hline Station Location & Sedimentation Rates" & Water Level Change & Source of ${ }^{19} \mathrm{Cs}$ Data \\
\hline Chenier Plain, southwestern LA & 0.67 & $\begin{array}{c}0.72-0.73 \\
(1,2,3)\end{array}$ & Delaune et al. 1983 \\
\hline Barataria Bay & $0.59-0.75$ & $\begin{array}{c}0.67-0.74 \\
(51-53,55)\end{array}$ & Hatton et al. 1983 \\
\hline & 0.75 & $\begin{array}{c}0.52-0.74 \\
(22,51-53,55)\end{array}$ & DeLaune et al. 1978 \\
\hline $\begin{array}{c}\text { Barrier island south } \\
\text { of Barataria Bay }\end{array}$ & $0.55-0.78$ & $\begin{array}{l}0.67 \\
(22)\end{array}$ & DeLaune et al. 1986 \\
\hline $\begin{array}{l}\text { Terrebonne marshes, } \\
\text { central LA coast } \\
\text { (exclusive of Wax Lake outlet marsh) }\end{array}$ & $0.65-0.91$ & - & DeLaune et al. $1987^{\circ}$ \\
\hline
\end{tabular}

imentation "excess"; this situation probably occurred, for example, in 1962 and 1963. The results from the ${ }^{137}$ cesium dating method should be compared to an average water level record rather than changes from a specific year (e.g., 1963).

Finally, the long-term average annual change is quite miniscule compared to the monthly range in water levels (typically less than 1\%), making a determination of slight variations about the mean very difficult to detect.

The above is not meant to imply that other marshes which have fragmented or turned to open water have not undergone stress caused by too low sedimentation rates. Sediments, of course, build and sustain marshes against a rising water level. But, strictly speaking, the data from the available sedimentation dating approaches cited herein could also be used to support the argument that marsh growth vertically is equal to relative water level rise when viewed over a time period of this century or even a few decades. Disparities may exist between sedimentation rates and relative water level rise (disparities certainly exist in local instances), but the ability of the marsh to survive these disparities is largely unexplored and may be significant. For example, salt marshes, like floating fresh marshes, can stretch with changing water levels (Harrison 1975), and sedimentation rates are influenced by vegetation structure as well as elevation (Ranwell 1964, 1972).

\section{ACKNOWLEDGMENTS}

K. Ramsey kindly assisted in checking data from the original data logs. She and S. Penland first prepared the analyses which drew attention to the material discussed herein. S. Kaswadji entered data for computer analyses. J. Cowan assisted in the statistical analyses and W. W. Wiseman, Jr. lent a friendly ear when the inevitable problem arose. J. Donley helped prepare the manuscript which benefits from the critical reviews of $P$.
'Templet, H. Roberts, R. Delaune, and two unidentified reviewers. This manuscript results from a chapter from a study report funded by a Minerals Management Services contract to LSU, RE'T, Program Manager (Turner and Cahoon 1987). The principal investigators for that project made numerous useful comments as this study progressed. The Louisiana Sea Grant Program also supported the preparation of the manuscript.

\section{Literature Cited}

Anonymous. 1965. Manual of Tide Observations. Publication 30-1, U.S. Department of Commerce, Coast and Geodetic Survey. U.S. Government Printing Office, Washington, D.C. Barnett, T. P. 1984. The estimation of "global" sea-level change: A problem of uniqueness. Journal of Geophysical Research 89:7980-7988.

BaumanN, R. H. 1980. Mechanisms of maintaining marsh elevation in a subsiding environment. M.S. Thesis. Louisiana State University, Baton Rouge. 90 p.

Baumann, R. H. and R. E. Turner. 1990. Direct impacts of outer continental shelf activities on wetland loss in the central Gulf of Mexico. Environmental Geology and Water Resources 15: 189-198.

Bradley, R. S., H. F. Diaz, J. K. Eischeid, P. D. Jones, P. M. Kelly, and C. M. Goodness. 1987. Precipitation fluctuations over northern hemisphere land areas since the mid19th century. Science 237:171-175.

Chew, F. 1964. Sea-level changes along the northern coast of the Gulf of Mexico. Transactions of the American Geophysical Union. 41:272-280.

DeLaune, R. D. 1986. 'The use of $\delta^{19} \mathrm{C}$ signature of C-3 and C-4 plants in determining past depositional environments in rapidly accreting marshes of the Mississippi River Deltaic Plain. Isotope Geoscience 59:315-320.

Delaune, R. D., R. H. Baumann, and J. G. Gosselink. 1983. Relationships among vertical accretion, coastal submergence and erosion in a Louisiana Gulf Coast marsh. Journal of Sedimentary Petrology 53:147-157.

Delaune, R. D., W. H. Patrick, JR., and R. J. Buresh. 1978. Sedimentation rates determined by Cs- 137 dating in a rapidly accreting salt marsh. Nature 275:532-533.

Delaune, R. D., C. J. Smith, and W. H. Patrick, JR. 1986 a. Sedimentation patterns in a Gulf Coast backbarrier marsh: Response to increasing submergence. Earth Surface Processes and Landforms 1 1:484-490.

Delaune, R. D., C. J. Smith, and W. H. Patrick, JR. 1986 b. Land loss in coastal Louisiana: E.ffect of sea level rise and 
marsh accretion. Final Report: Louisiana Board of Regents. Laboratory for Wetland Soils and Sediments, Center for Wetland Resources. Louisiana State University, Baton Rouge.

Delaune, R. D., C. J. Smith, W. H. Patrick, JR., and H. H. ROBERTs. 1987. Rejuvenated marsh and bay-bottom accretion on the rapidly subsiding coastal plain of U.S. Gulf coast: A second-order effect of the emerging Atchafalaya delta. Estuarine, Coastal and Shelf Science 25:381-389.

Frazier, D. E. 1967. Recent deltaic deposits of the Mississippi River, their development and chronology. Transactions of the Gulf Coast Assoriation of Geological Societies 17:287-315.

GoRnITZ, V. AND S. LEBEDEFF. 1987. Global sea-level changes during the past century, p. 3-16. In D. Nummendal, $\mathrm{O}$. H. Pilkey, and J. D. Howard (eds.). Sca-Level Fluctuations and Coastal Evolution. Society of Economic Paleontologists and Mineralogists, Tulsa, Oklahoma.

Gornitz, V., S. LEBEDEFF, AND J. HANSEN. 1982. Global sealevel trend in the past century. Science 215(4540):1611-1614.

Gosselink, J. G., R. Hatton, and C. S. Hopkinson. 1984. Relationship of organic carbon and mineral content to bulk density in Louisiana marsh soils. Soil Science 137:177-180.

HARrison, E. Z. 1975. Sedimentation rates, shoreline modification, and vegetation changes on tidal marshes along the coast of Connecticut. M.S. Thesis. Cornell University, Ithaca, New York. 107 p.

Hatton, R. S., R. D. Delaune, and W. H. Patrick, JR. 1983. Sedimentation, accretion and subsidence in marshes of Barataria Basin, Louisiana. Limnology and Oceanography 28:494502.

Holdahl, S. R. AND N. L. Morrison. 1974. Regional investigations of vertical crust movements in the U.S. using precise relevelings and mareograph data. Teclonophysics 23:373-390.

Lyles, S. D., L. E. Hickman, JR., And H. A. Debaugh, JR. 1988. Sea Level Variations for the United States 1855-1986. U.S. Department of Commerce, National Oceanic and Atmospheric Administration, National Ocean Service, Rockville, Maryland. $182 \mathrm{p}$.

Marmer, H. A. 1954. Tides and sea level in the Gulf of Mexico. Fishery Bulletin 89:101-118.

Patrullo, J., W. Munk, R. Revelle, and E. Strong. 1955. The seasonal oscillations in sea level. Journal of Marine Research 14:88-155.

Peltier, W. R. and A. M. Tushingham. 1989. Global sea level rise and the greenhouse effect: Might they be connected? Science 244:816-810.

Penland, S., K. E. Ramsey, R. A. McBride, J. T. Mestayer, and K. A. Westrhal. 1987. Relative sea level rise, delta plain development, subsidence and wetland sedimentation in the Teche and Lafourche delta complexes: Terrebonne Parish. Louisiana Final Rep., Louisiana Geological Survey, Coastal Geology Program. 236 p.

Penland, S., K. E. Ramsey, R. A. McBride, J. T. Mestayer,
AND K. A. Westrhal. 1988. Relative sea level rise and delta plain development in the Terrebonne Parish Region. Louisiana Geological Survey Coastal Geology Technical Report No. 4. Baton Rouge, Louisiana. 121 p.

Penland, S., K. F. Ramsey, R. A. McBride, T. F. Moslow, and K. A. Westphal. 1986. Relative sea level rise and subsidence in Louisiana and the Gulf of Mexico. Louisiana Geology Survey, Coastal Geol. Publ. Series, Tech. Rep., Baton Rouge, Louisiana. 35 p. + Appendices.

RAMSEY, K. E. AND T. F. Moslow. 1987. A numerical analysis of subsidence and sea level rise in Louisiana, p. 1673-1688. In Coastal Sediments.

RANwELl, D. S. 1964. Spartina salt marshes in southern England. I. Rate and seasonal pattern of sediment accretion. Journal of Ecology 52:79-94.

RANWELL, D. S. 1972. Ecology of Salt Marshes and Sand Dunes. Halsted Press. New York. $258 \mathrm{p}$.

Smith, L. M., J. B. Dunbar, AND L. D. Britsch. 1986. Geomorphological investigation of the Atchafalaya Basin, Area west, Atchafalaya delta, and Terrebonne Marsh. Vol. 1. Coastal Engineering Research Center, U.S. Army Corps of Engineers, Vicksburg, Mississippi. Tech. Rep. GL,-86-3.

Suhayda, J. N. 1987. Subsidence and sea level, p. 187-202. In R. E. Turner and D. R. Cahoon (eds.), Vol. 2. Technical Narrative. Final report submitted to Minerals Management Service, New Orleans, Louisiana. Contract No. 14-12-00130252. OCS Study/MMS 87-0119.536 p.

Swanson, R. L. AND C. I. Thurlow. 1973. Recent subsidence rates along the Texas and Louisiana coasts as determined from tide measurements. Journal of Geophysical Research 78: 2665-2671.

Swenson, E. M. And R. E. Turner. 1987. Spoil banks: Fffects on coastal marsh water level regime. Estuarine and Coastal Shelf Science 24:599-609.

'TEMPLET, P. 1987. The policy roots of Louisiana's land loss crisis, p. 714-725. In O. T. Magoon and others (eds.), Coastal Zone 87. Proc. 5th Symposium on Coastal and Ocean Management, Vol. 3. American Society of Civil Engineers, New York.

TURNer, R. E. AND D. R. Cahoon (EDs.). 1987. Causes of Wetland Loss in the Coastal Central Gulf of Mexico. Final rep. submitted to Minerals Management Service, New Orleans, Louisiana. Contract No. 14-12-001-30252. OCS Study/ MMS 87-0119. $536 \mathrm{p}$.

WhITAKER, R. E. 1971. Seasonal variations of steric and recorded sea level of the Gulf of Mexico. Office of Naval Research Contract Rep. N00014-68-A-0308-0002. Ref. 71-14T. $110 \mathrm{p}$.

Received for consideration, August 30, 1989 Accepted for publication, October 26, 1990 